\title{
MOTIVASI PENGUSAHA MUSLIM MEMPRODUKSI PRODUK IMITASI (Studi Pada Sentra Industri Kerajinan Kulit Di Tanggulangin) "
}

\author{
Firmansyah Aditama \\ Mahasiswa Program Studi S1 Ekonomi Islam - Fakultas Ekonomi dan Bisnis - Universitas Airlangga \\ Email : virmansyahh@gmail.com \\ Irham Zaki \\ Departemen Ekonomi Syariah - Fakultas Ekonomi dan Bisnis - Universitas Airlangga \\ Email : irhamzaki0712@gmail.com
}

\begin{abstract}
:
The purpose of this research is to know motivations which encourage moslem entrepreneurs decide producing imitation product.

This research used a qualitative approach with explanatory case study strategy which is able to answer the question arised. Data collecting process was done by interviewing moslem entrepereneurs in Tanggulangin. Analysis technique which used in this research is descriptive, because author tried to describe a symptoms, occurance, and events which happened nowadays. Author tried to capture events and occurance that happened and being a central of attention to be explained as it seen on the location.

The result showed that there are many forms of motivation why moslem entrepreneurs decide to produce imitation products. Those motivations were classified and explained based on the Islamic motivation theory by Abdul Hamid Mursi. That motivation theory is physiological motivation, psychological or social motivation, and working and producing motivation
\end{abstract}

\section{Keywords: Islamic motivation, moslem entrepreneurs}

\section{PENDAHULUAN}

Perekonomian menjadi nyawa bagi setiap manusia, masyarakat, bangsa, dan Negara. Disadari atau tidak bahwa setiap manusia di dunia ini tidak akan bisa lepas dari dunia perekonomian. Usaha manusia dalam rangka mewujudkan kesejahteraan hidup di muka bumi sangat berkaitan erat dengan kegiatan ekonomi.

Kegiatan ekonomi adalah kegiatan yang dilakukan manusia untuk memenuhi kebutuhannya. Dapat pula dikatakan, kegiatan ekonomi adalah kegiatan manusia untuk mencapai kesejahteraan. Menurut pandangan Islam, kegiatan ekonomi yang sesuai dan dianjurkan adalah melalui kegiatan bisnis dan juga investasi.
Bisnis dalam Islam dapat dipahami sebagai rangkaian aktivitas bisnis dalam berbagai bentuknya yang tidak dibatasi jumlah/kuantitas kepemilikan hartanya (barang/jasa) termasuk profitnya, namun dibatasi dalam cara perolehan dan pendayagunaan hartanya ada aturan halal dan haram (Zaroni, 2007).

Era globalisasi menjanjikan suatu peluang dan tantangan bisnis baru bagi perusahaan yang beroperasi di Indonesia. Di satu sisi, era globalisasi memperluas pasar produk dari perusahaan Indonesia. Di sisi lain, keadaan tersebut memunculkan persaingan yang semakin ketat baik antar perusahaan domestik maupun perusahaan asing. Akibat dari ketatnya persaingan ini 1) Jurnal ini merupakan bagian dari skripsi dari Firmansyah Aditama, NIM : 041014035, yang diuji pada 6 Februari 2015. 
banyak perusahaan yang melakukan imitasi.

Menurut Syafrizal dalam Albar (2012:64) Produk imitasi merupakan produk yang diciptakan dengan mengacu atau meniru pada produk pionir. Imitasi dapat dilakukan dengan meniru desain, membuat produk generik dengan harga yang lebih murah, dan melakukan beberapa penyempurnaan dari produk terdahulu. Schnaars dalam Hasnin (2012:55) imitasi adalah mengkopi, dimana imitator secara terus menerus meniru produk pionir.

Sekarang ini banyak beredar barang tiruan yang menggunakan merek dari perusahaan yang telah mapan. Hal ini dilakukan oleh perusahaan pembuat merek imitasi untuk mempermudah pemasaran barang tiruan tersebut dengan cara yang tidak etis. Banyak konsumen yang secara sadar dan sukarela membeli merek imitasi dengan beberapa alasan, antara lain karena harganya lebih murah, kualitas merek imitasi relatif hampir sama dengan merek yang asli, serta prestis yang diperoleh dengan menggunakan merek yang sudah terkenal.

Pada Tahun 2010 peredaran barang palsu dan ilegal di Indonesia mengalami kenaikan, yakni Rp 43 triliun. Pernyataan itu diucapkan wakil menteri perdagangan Indonesia (Wamendag), Bayu Krisnamurthi. Dia menjelaskan, nilai nominal Rp 43 triliun merupakan hasil penelitian dari Universitas Indonesia (UI) pada 2010 sampai tahun 2012, Kemendag sudah menangkap 762 pelanggaran barang beredar, diantaranya berkaitan dengan barang palsu. (www.republika.co.id :2012 diakses 27 agustus 2014)

Masyarakat Indonesia Anti Pemalsuan (MIAP) memaparkan hasil survei terbarunya mengenai peredaran produk palsu terhadap kerugian ekonomi nasional tahun 2014. Menurut Ketua MIAP Widyaretna Buenastuti, total kerugian akibat peredaran barang palsu tahun 2014 mencapai Rp 65,1 triliun. kerugian tersebut terdiri dari produk makanan dan minuman sebesar Rp 13,39 triliun, produk pakaian dan barang dari kulit sebesar $\operatorname{Rp} 41,58$ triliun, produk obat-obatan dan kosmetik sebesar Rp 6,5 triliun, serta produk software dan tinta sebesar Rp 3,6 triliun. (http://m.liputan6.com : 2014 diakses tanggal 22 November 2014)

Para ulama di Tanah Air turut memberikan perhatian yang serius terhadap maraknya praktik pelanggaran HAKI. Majelis Ulama Indonesia (MUI) telah menetapkan Fatwa Nomor 1 Tahun 2003 tentang Hak Cipta dan Fatwa Nomor 1/MUNAS VII/MUI/15/2005 tentang HAKI. Tidak hanya hanya melanggar agama, tetapi praktek ilegal itu juga dinilai melanggar ketentuan syariat. Surat anNisa' ayat 29 secara tegas melarang memakan harta orang lain cara batil (tanpa hak).

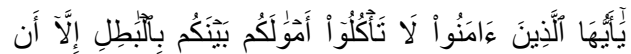

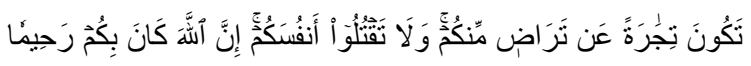
rq

Yā ayyuha'l-lażina āmanū lā ta'kulū baynakum bilbāțili illā-an takūna tijāratan 
'antarāọi'n-minkum. Wa lā taqtulū anfusakum. Inna'l-laha kānabikum rahìman

"Hai orang beriman! Janganlah kamu saling memakan harta sesamamu dengan jalan yang batil, kecuali dengan jalan perniagaan yang berlaku dengan suka sama-suka di antara kamu. Dan janglah kamu membunuh dirimu; sesungguhnya Allah adalah Maha Penyayang kepadamu."

Selain itu, Rasullullah bersabda "barang siapa yang melakukan penipuan/kecurangan, maka dia bukanlah dari golongan kami." (HR. Muslim, no. 164).(Ziyad Ghazal, Masyru' Qanun Al Buyu' fi ad Daulah Al Islamiyyah, hlm.133134).

Berdasarkan ayat dan hadist tersebut dapat disimpulkan bahwa Allah dengan tegas melarang umatnya untuk saling memakan harta sesamamu dengan jalan yang batil. Sebagai contoh adalah produksi barang imitasi, karena bisinis ini dapat merugikan salah satu pihak.

Berdasarkan uraian di atas, penelitian ini bermaksud mengetahui "motivasi pengusaha muslim memproduksi barang imitasi". Tempat yang akan dijadikan sebagai objek pada penelitian ini adalah pengusaha muslim di Tanggulangin. Objek penelitian ini dipilih, karena Tanggulangin merupakan salah satu tempat produksi barang imitasi di Sidoarjo.

\section{Rumusan Masalah}

Apa motivasi pengusaha muslim memproduksi produk imitiasi?

\section{Tujuan Penelitian}

Penelitian ini bertujuan untuk mengetahui untuk mengetahui motivasi pengusaha muslim memproduksi produk imitasi.

\section{LANDASAN TEORI}

\section{Pengertian Motivasi}

Kata motivasi memiliki beberapa pengertian, dari sisi Bahasa motivasi berasal dari kata motive atau dengan prakata Bahasa lainnnya, yaitu movere yang berarti "mengerahkan", atau memberikan dorongan yang menjadi pangkal sseseorang melakukan sesuatu (Rivai dan Arifin, 2009:386). Menurut Rivai (2004:455) motivasi sebagai serangkaian sikap dan nilai-nilai yang memperngaruhi individu untuk mencapai hal spesifik sesuai dengan tujuan individu.

Maka dapat simpulkan motivasi adalah upaya untuk mendorong sesorang kearah pencapaian tujuan berdasarkan kemampuannya untuk memuaskan kebutuhan individu tersebut.

\section{Motivasi dalam perspektif Islam}

Mursi (1997:107) menyebutkan macam-macam motivasi dalam pendekatan Al Qur'an dan Sains, yaitu sebagai berikut:

1. Motivasi Fisiologis

Allah SWT telah memberikan ciri ciri khusus pada setiap makhluk sesuai dengan fungsi - fungsinya. Diantara ciri ciri khusus terpenting dalam tabiat penciptaan hewan dan manusia adalah motivasi fisiologis. Studi- studi fisiologis menjelaskan adanya kecenderungan alami dalam tubuh manusia unutuk menjaga keseimbangan secara permanen. Apabila keseimbagan itu lenyap, maka timbul motivasi untuk 
melakukan aktivitas yang bertujuan mengembalikan kesimbangan tubuh seperti semula. Sehingga, manusia senantiasa menjaga keseimbangan vital yang lazim untuk menjaga diri, eksistensi, dan kesinambungan dalam menjalankan fungsi - fungsinya.

Setiap makhluk hidup diciptakan dengan cara dan ukuran tertentu, sehingga mencapai tingkat kesimbangan yang ideal. Apabila keseimbangan ini mulai tidak serasi, maka motivasi - motivasi fisiologis akan melakukan aktivitas yang pasti mengembalikan tubuh kepada keadaan semula, yaitu keseimbangan. Pemikiran mengenai keseimbangan tersebut telah dikupas dalam Al-Qur'an sebagai berikut

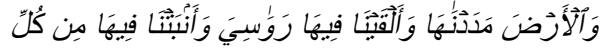

$$
\begin{aligned}
& \text { شَيَّيُ مَّوُْون } 19
\end{aligned}
$$

Wal arda madadnāha wa alqaynā fîha rawāsiya wa an batnā fihā min kulli syay-i'm-mauzūnin

"Dan Kami telah menghamparkan bumi dan menjadikan padanya gununggunung dan Kami tumbuhkan padanya segala sesuatu menurut ukuran." (QS. Al Hijr ayat 19)

\section{Motivasi psikologis atau sosial}

Berikut ini merupakan macammacam motivasi psikologis atau sosial dalam perspektif Islam, yaitu:

a. Motivasi kepemilikan: Motivasi psikologis yang dipelajari masnusia di tengah pertumbuhan sosialnya. Di dalam fase pertumbuhan, berkembang kecenderungan individu untuk memiliki. Individu tersebut berusaha mengakumulasi harta yang dapat memenuhi kebutuhan dan jaminan keamanan hingga masa yang akan datang.

b. Motivasi berkompetisi: Berkompetensi (berlomba-lomba) merupakan dorongan psikologis yang diperoleh dengan mempelajari lingkungan dan kultur yang tumbuh di dalamnya. Manusia biasa berkompetensi dalam ekonomi, keilmuan, kebudayaan, sosial, dan sebagainya. Al Qur'an menganjurkan manusia agar berkompetensi dalam ketakwaan, amal shaleh, berpegang pada prinsip - prinsip kemanusiaan, dan mengikuti manhaj Illahi dalam hubungan dengan sang pencipta dan sesama manusia, sehingga memperoleh ampunan dan keridhan Allah SWT

c. Motivasi kerja: motivasi kerja dimiliki oleh setiap manusia, tetapi ada sebagian orang yang lebih giat bekerja daripada yang lain. kebanyakan orang mau bekerja keras jika tidak menemui hambatan dalam merealiasasikan apa yang diharapkan. Selama dorongan kerja itu kuat, semakin besar peluang individu untuk lebih konsisten pada tujuan kerja. Ada juga yang lebih menyukai dorongan kerja tanpa mengharapkan imbalan, sebab ia menemukan kesenangan dan kebahagiaan dalam perolehan kondisi yang dihadapi dan dalam mengatasi situasi yang sulit.

3. Motivasi dalam Bekerja dan Berproduksi 


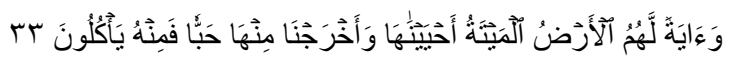

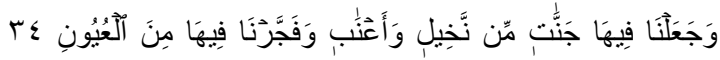

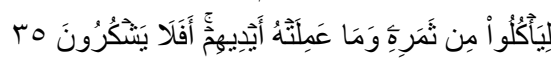

Wa ā yatu'l-lahumul ardu'l-maytatu ahyaynāhā wa akhrajnā minhā habban faminhu ya'kulūna. Wa ja'alna fihā min nakhiiliw wa a'nābin wafajjarnā fihā mina'l'uy ūni. Liya'kulū min siamarihī wa mā 'amilathu aydīhim. Afalā yasykurūna.

33. Dan suatu tanda (kekuasaan Allah yang besar) bagi mereka adalah bumi yang mati. Kami hidupkan bumi itu dan Kami keluarkan dari padanya biji-bijian, maka daripadanya mereka makan.

34. Dan Kami jadikan padanya kebunkebun kurma dan anggur dan Kami pancarkan padanya beberapa mata air.

35. supaya mereka dapat makan dari buahnya, dan dari apa yang diusahakan oleh tangan mereka. Maka mengapakah mereka tidak bersyukur." (Q.S. Yasin 33-35)

Berdasarkan ketiga ayat tersebut, pertama menjelaskan bahwa hendaklah manusia bekerja didasarkan atas kepentingan berproduksi, sebagaimana dinyatakan dalam Alqur'an ".....dari apa yang diusahakan oleh tangan mereka." Usaha manusia dalam bekerja dan berproduksi tersebut tetap disandarkan pada kehendak Allah SWT, serta disertai doa memohon pertolongan-Nya. Kedua menjelaskan bahwa lingkungan adalah anugerah Allah SWT yang menyediakan hal-hal yang dapat membantu manusia dalam kehidupannya. Apabila anugerah Allah SWT tersebut disertai kesiapan berkarya yang disediakan pula bagi manusia sejak pertumbuhannya.

Islam mengajarkan bahwa setiap pekerjaan dan kenikmatan yang baik dapat berubah, menjadi ibadah apabila disertai niat tulus menjaga anugerah hidup dan memanfaatkannya, menghormati kehendak pemberinya. Oleh karena itu, seseorang yang beriman tapi tidak bekerja, maka akan hidup dalam kehampaan dan kelumpuhan, tidak ada hasil kongkret dalam hidupnya, serta tidak ada tanda keimanannya. Sebaliknya, seseorang yang bekerja tanpa iman akan hidup seperti robot dan tidak mampu merasakan eksistensi nilai-nilai dibalik penciptanya.

\section{Bisnis menurut Islam}

Yusanto (2002:18-21) memaparkan bahwa bisnis islami dikendalikan oleh aturan halal dan haram, baik secara perolehan maupun pemanfaatan harta;sementara bisnis non-islami tidak memperhatikan aturan halal dan haram dalam setiap perencanaan, pelaksanaan, dan segala usaha yang dilakukan dalam meraih tujuan. Dari asa sekularisme inilah, seluruh bangunan karakter bisnis non islami diarahkan pada hal-hal yang bersifat bendawi dan menafikan nilai ruhiah serta keterikatan pelaku bisnis pada aturan yang lahir dan nilai-nilai transdental. Kalaupun ada aturan, semata-mata bersifat etik yang tidak ada hubungannya dengan dosa dan pahala.

Bisnis islami hanya akan hidup secara ideal dalam sistem dan lingkungan yang islami pula. Dalam lingkungan yang tidak islami, pelaku bisnis akan mudah terseret dan sukar berkelit dalam kegiatan yang dilarang agama: mulai dari vang pelicin saat perizinan usaha, menyimpan vang dalam rekening koran yang berbunga, hingga iklan yang tidak selayaknya, dan sebagainya. 


\section{Strategi imitasi}

Menurut Shenkar dalam Hasnin (2012:54) peniruan adalah sebuah cara yang digunakan individu untuk belajar, merasakan, bertahan, bersaing, dan berkembang perlahan ketika mereka memperoleh sifat dan perilaku yang membantu mereka maju pesat dalam lingkungan masing-masing. Pandangan ini terjadi, karena ia melihat perilaku manusia sejak dari lahir, dimana anak akan belajar untuk meniru bahasa orang tuanya atau budaya masyarakat sekitar sebelum akhirnya dapat belajar dan mengembangkan dirinya sendiri.

Menurut Syafrizal dalam Albar (2012:64) Produk imitasi merupakan produk yang diciptakan dengan mengacu atau meniru pada produk pionir. Imitasi dapat dilakukan dengan meniru desain, membuat produk generik dengan harga yang lebih murah, dan melakukan beberapa penyempurnaan dari produk terdahulu. Schnaars dalam Hasnin (2012:55) imitasi adalah mengkopi, dimana imitator secara terus menerus meniru produk pionir.

Schnnars dalam fillianty (2006:4) menyebutkan bahwa imitasi tersebut dapat dilakukan dengan membajak sampai kepada membuat produk yang lebih baik dengan dasar produk pioneer. Oleh karena itu produk imitasi terdiri dari beberapa tingkatan, yaitu

1. Counterfits atau pembajakan pada tingkatan ini perusahaan benar-benar menjual produk dengan merk dan desain produk yang benar-benar sama sehingga sering disebut produk palsu. Imitasi ini tergolong illegal.

2. Knockoff atau cloning. Pada tingkatan ini perusahaan benar-benar meniru produk yang sudah ada tetapi memiliki merek lain. (hal ini tidak dipakai dalam penelitian)

3. Design copy atau trade dress. Pada tingkatan kemasan, tampilan atau desain merupakan bagian yang penting dan produk yang menggunakan strategi ini. Selanjutnya peniruan desain dipadukan dengan imitasi dan inovasi. Namun jika desain atau kemasan bukan bagian yang penting, maka yang dapat di tiru adalah teknologi atau kemasan bukan bagian yang penting, maka yang dapat ditiru adalah teknologi atau keunikan dan produk yang menjadi acuan. Pada tingkatan ini perusahaan menciptakan produk yang sangat menyerupai produk lain atau biasanya produk pionir atau market leader, tetapi tidak benar-benar sama. Pada tingkatan ini sering juga disebut dengan kombinasi antara strategi imitasi dan inovasi. Sesuai fungsinya untuk mengelabui konsumen sehingga melakukan kesalahan dalam pembelian, maka produk ini dapat juga disebut dengan istilah produk kamuflase. Strategi ini biasanya digunakan oleh pengikut pasar agar dapat menghindari berbagai biaya sehingga dapat berhadapan langsung dengan market leader, karena strategi ini cenderung untuk 
menciptakan produk yang hamper sama dengan market leader, tetapi dengan harga yang lebih rendah.

Komponen utama dalam strategi imitasi pada produk kamuflase dalam merebut perhatian konsumen terdiri dari:

- Packging yang dibuat mirip dengan market leader. Hal ini dilakukan untuk mengelabui konsumen secara visual.

- Promosi yang sama dengan market leader. Hal ini dilakukan untuk memberikan kesan atau positioning yang sama dibenak konsumen dengan produk yang menjadi market leader.

- Produk baru yang sama dengan market leader. Menciptakan produk yang sama atau lebih baik dibandingkan produk market leader.

- Harga yang lebih murah dibandingkan market leader. Harga merupakan hal yang cukup menjadi pertimbangan bagi konsumen.

- Merek yang hampir sama dengan market leader. Untuk beberapa produk terkadang hanya berbeda satu atau dua huruf dengan merek market leader.

- Strategi distribusi yang sama dengan market leader. Biasanya produk imitasi cenderung mengawali proses ini menjadi saluran distribusi dari produk market leader.

Imitasi jenis ini berada diantara daerah ilegal dan legal. Hal ini sangat bergantung pada kemampuan inovasi perusahaan, selain itu faktor hukum yang berlaku disuatu negara merupakan hal yang perlu diperhatikan oleh perusahaan. Undang-undang dibidang trade dress cenderung mengacu pada Hak dan Kekayaan Intelektual (HaKi) untuk menghindari adanya penjiplakan. (hal ini tidak dipakai dalam penelitian)

4. Creative adaptions. Perusahaan peniru berupaya meniru produk yang ada, kemudian mengembangkan atau mengadaptasikannya kepada lingkungan yang baru. (hal ini tidak dipakai dalam

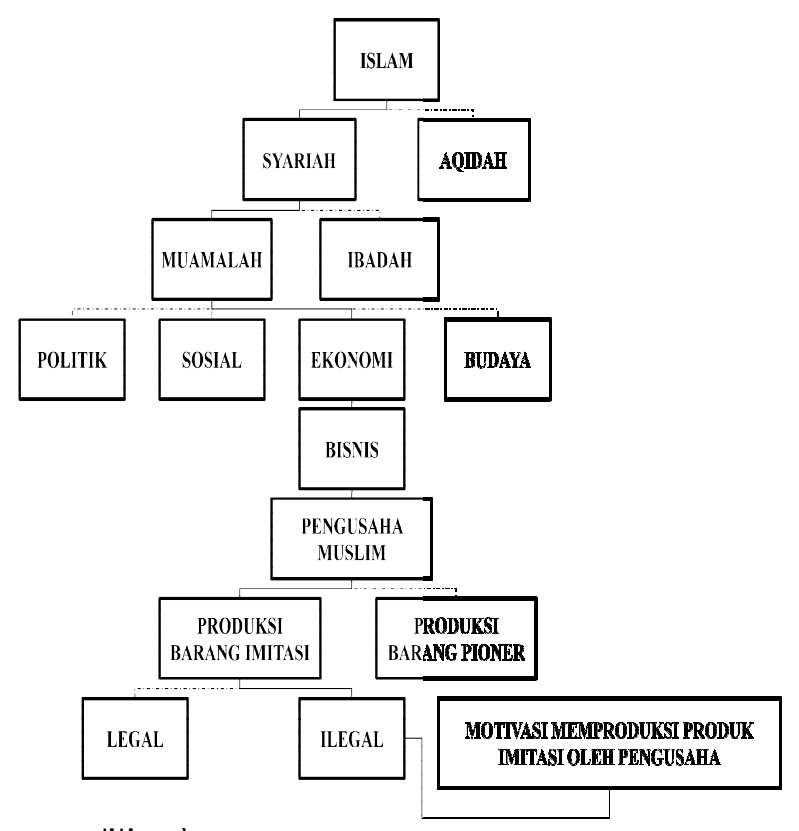
penelitian).

\section{Kerangka Berpikir}

Gambar 1.

Kerangka berpikir

Sumber: Penulis

Kerangka berfikir diatas menunjukkan bahwa Kerangka berfikir pada Gambar 1 menjelaskan ajaran islam bersumber dari syariah dan aqidah, dalam islam terdapat muamalah dan ibadah. Sebagaimana diungkapan diatas, Islam memberikan kesempatan kepada setiap pengusaha muslim untuk berproduksi, tetapi tetap dilandasi oleh nilai-nilai dan 
etika yang bersumber dari nilai-nilai dasar agama.

\section{METODE PENELITIAN}

\section{Pendekatan Penelitian}

Pendekatan yang digunakan dalam penelitian ini adalah dengan menggunakan pendekatan kualitatif. Menurut Sugiyono (2009:9), pendekatan kualitatif adalah penelitian yang berlandaskan pada filsafat postpositivisme dan digunakan untuk meneliti pada kondisi obyek yang alamiah, dimana peneliti sebagai instrumen kunci, teknik pengumpulan data dilakukan secara triangulasi (gabungan), analisa data bersifat induktif, dan hasil penelitian kualitatif lebih menekankan makna daripada generalisasi. Sesuai keterangan diatas, maka penelitian ini akan menggunakan strategi studi kasus dalam memahami masalah yang diteliti. Studi kasus adalah inkuiri empiris yang menyelidiki fenomena di dalam konteks kehidupan nyata, bilamana: batas-batas antara fenomena dan konteks tak tampak dengan tegas; dan dimana: multisumber bukti dimanfaatkan (Yin, 2009:18).

\section{Desain penlitian}

Metode penelitian studi kasus menurut Yin (2009:29) memiliki komponenkomponen desain penelitian sebagai berikut:

1. Pertanyaan penelitian

Metode penelitian studi kasus menyarankan peneliti untuk membentuk penrtanyaan siapa, apa, dimana, bagaimana, dan mengapa dalam memberikan rambu penting yang digunakan dalam strategi penulisan. Penelitian ini menggunakan pertanyaan "Apa motivasi yang membuat pengusaha muslim di tanggulangin masih memproduksi barang imitasie".

\section{Proposisi}

Proposisi digunakan untuk mengarahkan perhatian peneliti kepada sesuatu yang harus diselidiki dalam ruang lingkup penelitian sehingga hasil temuannya diharapkan lebih jelas dan spesifik. Proposisi juga mencerminkan isu teoritis yang penting yang menyatakan dimana peneliti harus mencari bukti yang dianggap cocok dan relevan. Proposisi dalam penilitian ini adalah motivasi pengusaha muslim memproduksi produk imitasi yang sudah jelas tidak sesuai atau melanggar prinsip produksi islami.

3. Unit-unit Analisis

Komponen ini berkaitan dengan masalah penentuan apa yang dimaksud dengan kasus dalam penelitian yang telah menjadi pembahasan di awal studi kasusnya. Menentukan unit analisis diperlukan dalam sebuah penelitian agar peneliti dapat mengetahui dan menentukan masalah dari penelitian tersebut. Oleh karena itu peneliti harus dapat menentukan apakah unit analisis yang digunakan dalam penelitian tersebut adalah individu, kelompok perusahaan, atau budaya.

4. Logika yang mengaitkan data dengan proposisi tertentu

Pengaitan data terhadap proposisi dapat dilakukan dengan banyak cara, namun tidak ada satupun yang dapat 
terdefinisi secara pasti. Satu pendekatan yang memberi harapan kepada studi kasus adalah gagasan mengenai penjodohan pola yaitu mengaitkan beberapa informasi kasus yang sama dengan beberapa proposisi teoritis. Pada penelitian motivasi pengusaha muslim menjadi faktor yang dapat dikaitkan antara proposisi dengan data yang ada.

5. Kriteria untuk menginterpretasikan temuan

Komponen kelima ini juga tidak memiliki satupun cara yang tepat yang dapat digunakan untuk menyusun kriteria guna menginterpretasikan tipe-tipe data temuan. Melalui temuan yang diperoleh berdasarkan perbandingan sekurangkurangnya dua proposisi yang bersaing, diharapkan pola-pola yang berbeda dapat memberikan gambaran yang cukup jelas. Peristiwa yang dimaksud dalam penelitian ini adalah adanya fenomena memproduksi barang imitasi pada generasi $Y$. Dalam penelitian ini generasi $Y$, adalah para pengusaha muslim di Tanggulangin yang memiliki pemahaman bisnis Islam. Pengusaha muslim yang memiliki pemahaman bisnis Islam, seharusnya tidak mengimitasi produk saudaranya sendiri.

\section{Teknik keabsahan data}

Penelitian ini menggunakan metode triangulasi teknik untuk mengecek data yang diperoleh dari informan mengenai motivasi pengusaha muslim memproduksi produk imitasi. Peneliti menggunakan teknik pengumpulan data yang berbeda-beda untuk mendapatkan data dari sumber yang sama, yaitu wawancara, observasi dan dokumentasi. Selain melakukan proses wawancara mendalam kepada informan, peneliti juga melakukan proses observasi ke tempat usaha atau rumah informan untuk mengetahui motivasi pengusaha muslim memproduksi produk imitasi, dengan cara melihat, mengamati, menganalisis dan mencatat fenomena yang ada dilapangan. Peneliti juga melakukan proses dokumentasi untuk memotret keadaan yang ada di lapangan, dokumentasi ini akan meningkatkan keabsahan penelitian, karena dokumentasi tersebut merupakan bukti bahwa peneliti benar-benar melakukan pengumpulan data.

\section{Teknik analisis}

Teknik analisis yang digunakan di dalam penelitian ini adalah deskriptif, karena peneliti berusaha mendeskripsikan suatu gejala, peristiwa, kejadian yang terjadi saat sekarang dimana peneliti berusaha memotret peristiwa dan kejadian yang terjadi menjadi pusat perhatiannya untuk kemudian dijabarkan sebagaimana adanya, sehingga analisis yang digunakan adalah membandingkan suatu temuan dan kajian proposisi yang telah dibuat sebelumnya. Tujuan dari perbandingan tersebut adalah menganalisis data studi kasus dengan cara membuat suatu penjelasan (naratif), dan menggambarkan (deskripsi) kasus yang bersangkutan dan membuktikan proposisi teoritis yang telah dibuat, akhir dari penelitian adalah membuat tulisan yang kaya akan gambaran detail dan mendalam 
mengenai objek penelitian (thick description). (Yin, 2009:1)

\section{HASIL DAN PEMBAHASAN}

\section{Gambaran subjek penelitian}

Produksi utama produsen di Tanggulangin adalah membuat tas. Mengikuti perkembangan zaman mereka juga mulai membuat sabuk, sepatu, jaket dan dompet. Secara keseluruhan produksi utama di Tanggulangin berbahan dasar dari kulit. Jumlah karyawan rata-rata yang dimiliki produsen di Tanggulangin berkisar kurang lebih 10-20, masing-masing karyawan yang memiliki keahlian khusus dibidangnya.

Terkenalnya Tanggulangin dalam hal kerajinan kulit juga terdengar oleh negara lain seperti pemerintah Italia yang ingin menguncurkan pinjaman sebesar 150 Milyar untuk mengembangkan industri sepatu di Tanggulangin, Sidoarjo Jawa Timur. Dana tersebut digunakan untuk membangun Pusat Pelatihan Persepatuan Kasual di sentra Industri kerajinan kulit.

\section{Hasil Analisis}

$$
\text { Manusia dalam segala }
$$

tindakannya, mulai dari apa yang pertama kali dilihat, diserap, yang kemudian mengendap menjadi suatu memori, dan pada akhirnya timbul suatu gerakan untuk melakukan apa yang diinginkannya merupakan suatu tahap motivasi. Manusia digambarkan sebagai makhluk yang mempunyai banyak kebutuhan. Manusia akan terus berusaha mendapatkan apa yang dibutuhkan (diinginkan), dan setelah kebutuhan pertama terpenuhi akan ada kebutuhan yang kedua, begitupun seterusnya. Adanya sebuah dorongan yang timbul dalam diri manusia atau bahkan yang berasal dari luar diri manusia memengaruhi pengambilan keputusan dan perilaku manusia. Berikut ini adalah motivasi yang mendorong pengusaha muslim di Tanggulangin

1. Informan pertama dalam objek penelitian pertama

Motivasi Informan pertama memproduksi produk imitasi adalah menjaga keberlangsungan hidup perusahaan dan agar perusahaan terhindar dari ketidak keseimbangan, karena dengan terus memproduksi produk imitasi dengan kualitas terbaik serta menjaga ketersediaan produk yang diinginkan konsumen maka akan muncul kepuasan dan loyalias konsumen. (motivasi fisologis)

Motivasi informan pertama yang lainnya adalah memproduksi produk imitasi merupakan kebutuhan bagi perusahaan, karena hal tersebut merupakan tuntuan konsumen yang pada dasarnya lebih suka membeli produk dengan merk yang lebih bervariasi. Memproduksi produk imitasi juga dapat menaikkan pendapatan perusahaan dan bersaing dengan perusahaan lain dengan cara melakukan inovasi sehingga tamu akan selalu berdatangan. (Motivasi psikologis atau sosial: kepemilikan)

Selain itu motivasi informan pertama yang lainnya adalah memproduksi produk imitasi juga salah satu wujud perintah Allah untuk bekerja dengan 
mempekerjakan bukan angkatan kerja (motivasi bekerja dan berproduksi).

2. Informan kedua dalam objek penelitian pertama

Motivasi Informan kedua memproduksi produk imitasi adalah menjaga keberlangsungan hidup perusahaan, karena tingkat penjualan produk imitasi cukup besar ketika diadakan obral dan semua produk imitasi yang diproduksi laku terjual dalam program obral atau sale. (motivasi fisiologis)

Selain itu motivasi informan kedua lainnya adalah memproduksi produk imitasi merupakan kebutuhan yang harus dipernuhi perusahaan, karena Informan kedua biasa melakukan obral atau sale yang ditujukan untuk menarik minat para konsumen dan biasanya produk yang diobral merupakan produk-produk imitasi sehingga hal tersebut dapat menaikkan pendapatan perusahaan. (motivasi psikologis atau sosial).

Motivasi informan kedua berikutnya adalah memproduksi produk imitasi juga salah satu wujud perintah Allah untuk bekerja, karena bekerja dengan jujur akan membuat semua urusan bisnis menjadi lancar (motivasi bekerja dan berproduksi).

3. Informan ketiga dalam objek penelitian pertama

Motivasi Informan ketiga memproduksi produk imitasi adalah menjaga kelangsungan hidup perusahaan dan agar terhindar dari ketidakkeseimbangan, karena penjualan yang selalu stabil. (motivasi fisiologis)
Motivasi informan ketiga berikutnya adalah memproduksi produk imitasi merupakan kebutuhan bagi perusahaannya, karena masyarakat Indonesia lebih menyukai produk yang bermerk dari luar di banding merk lokal tanpa memerhatikan keaslian merk dari komoditi yang dibeli dan membuat produk dengan merk sendiri bisa menghabiskan biaya. (motivasi psikologis atau sosial)

Selain itu motivasi informan ketiga lainnya adalah memproduksi barang imitasi merupakan salah satu pekerjaan dengan cara yang halal dan hal tersebut merupakan wujud perintah Allah untuk bekerja maka dari itu informan ketiga masih terus memproduksi produk imitasi hingga saat ini. (motivasi bekerja dan berproduksi)

4. Informan keempat dalam objek penelitian kedua

Motivasi Informan keempat memproduksi produk imitasi adalah sebuah kebutuhan perusahaan, karena dengan memproduksi produk imitasi, perusahaan bisa memperoleh peningkatan pendapatan. Selain itu masyarakat Indonesia masih menyukai barang bermerk. (Motivasi psikologis dan sosial)

Selain itu motivasi informan keempat lainnya adalah setiap pekerjaan merupakan ibadah kepada Allah SWT, karena setiap usaha atau pekerjaan harus diimbangi doa agar mencapai kesuksesan, dan memproduksi produk imitasi merupakan pekerjaan sekaligus wujud 
perintah Allah untuk bekerja (motivasi bekerja dan berproduksi).

5. Informan kelima dalam objek penelitian kedua

Tingginya tingkat pembelian masyarakat Indonesia terhadap produk imitasi memotivasi informan kelima memproduksi produk imitasi dan menjadi kebutuhan yang harus dipernuhi perusahaan. Selain itu dengan memproduksi produk imitasi dapat menaikkan pendapatan perusahaan. (motivasi psikologis atau sosial)

Motivasi informan kelima berikutnya adalah meskipun dengan cara yang salah memproduksi produk imitasi juga salah satu wujud perintah Allah untuk bekerja, karena informan kelima selain berusaha selalu berdoa kepada Allah SWT. (motivasi bekerja dan berproduksi) .

\section{Pembahasan}

Bisnis diartikan sebagai suatu kegiatan yang dilakukan oleh manusia untuk memperoleh pendapatan dalam rangka memenuhi kebutuhan dan keinginan hidupnya dengan cara mengelola sumber daya ekonomi secara efektif dan efisien. Pelaku bisnis akan melakukan bisnis dalam bentuk: (1) memproduksi dan mendistribusikan barang atau jasa, (2) mencari profit, (3) mencoba memuaskan keingingan konsumen. Tetapi seorang Muslim dalam menjalankan bisnisnya ini tidak boleh mencari laba maksimal semungkin, harus ada batasannya. Demikian pula, berbisnis harus dilakukan dengan cara saling menguntungkan sehingga tidak menimbulkan kerugian sedikitpun baik pada waktu dilakukan setelahnya. Hal ini secara tegas dijelaskan dalam Al Qur'an surat an Nisa' ayat 29:

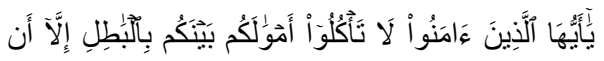

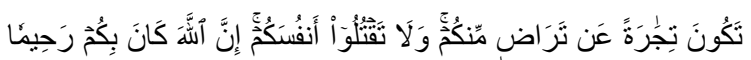
rq

Yā ayyuha'l-lażīna āmanū lā ta'kulū amwālakum baynakum bilbāțili illā an takūna tijāratan 'an taraḍi'm-minkum. Wa lā taqtulū anfusakum. Inna'l-laha kāna bikum rahiman.

Artinya: "Hai orang-orang yang beriman, janganlah kamu saling memakan harta sesamamu dengan jalan yang batil, kecuali dengan jalan perniagaan yang berlaku dengan suka sama-suka di antara kamu. Dan janganlah kamu membunuh dirimu; sesungguhnya Allah adalah Maha Penyayang kepadamu."

Paparan di atas menegaskan, pertama Al Qur'an memberikan tuntutan bisnis yang jelas yaitu visi bisnis masa depan yang bukan semata-mata mencari keuntungan sesaat, melainkan mencari keuntungan yang hakiki, dan berakibat baik pula bagi kesudahannya. Kedua, keuntungan bisnis menurut Al Qur'an bukan sekedar bersifat material, tetapi bersifat material sekaligus immaterial, bahkan lebih mengutamakan hal yang bersifat immaterial dan kualitas. Ketiga, bisnis bukan semata-mata berhubungan dengan manusia tetapi juga berhubungan dengan Allah. Dengan demikian, terkait bisnis, dalam Al Qur'an secara otomatis sudah terdapat implementasi etika bisnis.

$$
\text { Selanjutnya Yusanto (2002:18-21) }
$$

memaparkan bahwa bisnis islami dikendalikan oleh aturan halal dan haram, baik secara perolehan maupun 
pemanfaatan harta;sementara bisnis nonislami tidak memperhatikan aturan halal dan haram dalam setiap perencanaan, pelaksanaan, dan segala usaha yang dilakukan dalam meraih tujuan. Dari asa sekularisme inilah, seluruh bangunan karakter bisnis non islami diarahkan pada hal-hal yang bersifat bendawi dan menafikan nilai ruhiah serta keterikatan pelaku bisnis pada aturan yang lahir dan nilai-nilai transdental. Kalaupun ada aturan, semata-mata bersifat etik yang tidak ada hubungannya dengan dosa dan pahala.

Hal ini bertentangan dengan motivasi pengusaha muslim di Tanggulangin yang memproduksi produk imitasi dilapangan. Menurut Schnaars dalam Hasnin (2012:55) imitasi adalah mengkopi, dimana imitator secara terus menerus meniru produk pionir. Counterfits atau pembajakan pada tingkatan ini perusahaan benar-benar menjual produk dengan merk dan desain produk yang benar-benar sama sehingga sering disebut produk palsu. Imitasi ini tergolong ilegal. Berdasarkan hasil wawancara Informan pertama hingga kelima termotivasi memproduksi produk imitasi dikarenakan pendapatan yang stabil dan menjanjikan.

Padahal memproduksi imitasi sendiri merugikan bagi perusahaan yang mempunyai merk atau hak cipta atas produknya dan termasuk haram hukumnya. Menurut (Kelana, 2008:1 12), Hal ini juga bertentangan dengan Anjuran berbisnis Rasullullah SAW. Apa yang haram telah jelas menjadi larangan Allah SWT atas kaum muslim. Karena itu, memperjualbelikan barang-barang haram akan jatuh pada perbuatan haram, termasuk juga mengusahakan seseuatu dengan cara yang haram meskipun obyeknya adalah benda yang halal.

أفلا جعلته فوق الطعام حتى يراه الناس! من غشنا فليس sis

Afa lā ja'altahu fawqa a'ț-ța'amu ḥatta yurāhu linnāsi! Man gisynā falaysa minnā

Artinya: "Mengapa engkau tidak meletakkannya di bagian atas, agar orang yang akan membeli dapat melihatnya? Barangsiapa yang berbuat curang kepada kami, maka ia bukan bagian dari golongan kami." (HR Muslim)

Menurut Said (2008:5) menyebutkan faktor-faktor produksi dalam Islam, Islam mengajarkan agar barang yang diproduksi adalah barang halal bukan barang haram. Barang atau produk yang haram adalah sesuatu dzat (benda), sebagaimana yang tersebut dalam Al Qur'an yang dilarang oleh Allah untuk memakannya, dan barang siapa yang melanggar maka berdosa. Sedangkan barang atau produk yang halal adalah sesuatu dzat (benda) yang tersebut dalam Al-Qur'an yang diperbolehkan oleh Allah dan halal untuk dimakan.

Al-Qur'an melarang makan produk yang haram dan memerintahkan memakan produk bagi yang halal. Dalam surat Al Baqarah: 172

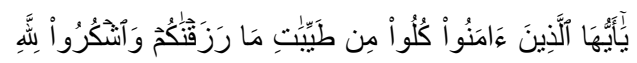

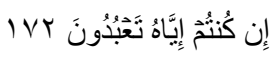

$$
\begin{aligned}
& \text { Yā ayyuha'l-lażīna āmanū kulū }
\end{aligned}
$$


Artinya: "Hai orang-orang yang beriman, makanlah di antara rezeki yang baik-baik yang Kami berikan kepadamu dan bersyukurlah kepada Allah, jika benarbenar kepada-Nya kamu menyembah".

Dengan tidak terpenuhinya Anjuran Bisnis Rasullullahah serta cara berproduksi menurut perspektif Islam, maka dapat dikatakan hal yang memotivasi pengusaha muslim di Tanggulangin ini hanya sebatas mencari pendapatan atau keuntungan, tidak mencari kemantapan dari usaha itu sendiri dengan memperoleh keuntungan yang wajar dan di ridhoi oleh Allah SWT.

\section{SIMPULAN}

Berdasarkan analisa dan pembahasan motivasi pengusaha muslim memproduksi produk imitasi. Berikut ini dapat ditarik beberapa kesimpulan mengenai pembahasan ini, diantaranya:

1. Memproduksi produk imitasi dilakukan oleh pengusaha muslim karena tingginya minat masyarakat Indonesia terhadap produk imitasi, sehingga menjadi kebutuhan yang harus dipenuhi oleh perusahaan.

2. Motivasi lain yang mendasari para informan memproduksi produk imitasi adalah Dengan memproduksi produk imitasi akan menjaga keberlangsungan hidup perusahaan dikarenakan tingkat penjualan produk imitasi menjanjikan dan stabil dari tahun ketahun.

3. Motivasi pengusaha muslim ini bertentangan dengan anjuran berbisnis Rasullullah SAW dan cara berproduksi dalam perspektif Islam, karena hal ini merugikan perusahaan yang mempunyai merk atau hak cipta atas produknya.

Saran yang direkomendasikan setelah melakukan penelitian motivasi pengusaha muslim memproduksi produk imitasi adalah sebagai berikut:

1. Bagi pengusaha muslim di Tanggulangin dengan melakukan hak paten atas produk dan pemasaran, produk Industri kerajinan kulit Tanggulangin akan lebih dikenal tanpa melakukan pengimitasian, karena pengimitasian tersebut sangat merugikan dalam waktu jangka panjang.

2. Untuk pemerintah seharusnya lebih ketat dalam menanggulangi pengimitasian produk dan memberikan fasilitas agar produk hasil lokal lebih dikenal di Pasar Domestik.

\section{DAFTAR PUSTAKA}

Albar, Berri Brilliant, S.E, M.M. 2012. Jurnal Manajemen dan Kewirausahaan: Pengaruh Strategi Imitasi Rokok Country terhadap Keputusan Pembelian Konsumen. Jurnal tidak diterbitkan. Padang. Fakultas Ekonomi, Universitas Tamansiswa

Djakfar, Muhammad.2012, Etika Bisnis Menangkap Spirit Ajaran Langit dan Peran Moral Ajaran Bumi. Jakarta

Fillianty, Fitry. 2006. Jurnal Teknik Industri. Strategi Imitasi dan Manajemen Pengetahuan Alam Pengembangan Inovasi PLA (Poly Lactic Acid) pada Agro Industri Kemasan Bodegradabel di Indonesia. Jurnal tidak di terbitkan, 
Bogor. Teknis Industri, Institut Pertanian Bogor

Hasnin, Hannisa Rahmaniar. 2011. Inovasi produk melalui strategi imitasi dalam menghadapi persaingan produk impor (implementasi Strategi Imitasi pada Studi Kasus Edam Burger Depok). Skripsi tidak diterbitkan. Jakarta. Fakultas IImu Sosial dan IImu Politik, Universitas Indonesia

Jusmailindkk. 2008. Bisnis Berbasis Syariah. Jakarta: Bumi Aksara

Mursi, Abdul Hamid. 1997. SDM yang Produktif: Pendekatan Terapan. Jilid 1. Jakarta: PT. Indeks

Noor, Muhammad labal. 2012. Motivasi Islam dan Motivasi Proposial pada Lembaga Amil Zakat( Studi terhadap Para Pegawai PKPU Cabang Semarang. Skripsi tidak diterbitkan. Semarang Fakultas Ekonomika dan Bisnis Universitas Diponegoro

Rivai dan Arviyan Arifin, 2009. Islamic Leadership, membangun superleadership melalui kecerdasan spiritual, Jakarta: Bumi Aksara

Rivai, Veithzal. 2004. Manajemen Sumber Daya Manusia untuk Perusahaan dari Teori ke Praktik, Jakarta: PT Raja Grafindo Persada

Said, Syihabudin dan Ma'zumi.2008. Falsafah dan Perilaku Ekonomi Islam. Cetakan Pertama. Jakarta. Diadit Media

Sugiyono, 2011. Metode Kuantitatif, Kualitatif, dan R\&D, Bandung: Alfabeta Taufiq, Muhammad Izzuddin. 2006. Islamic Business Srategy for Entrepreneurship (Bagaimana Menciptakan dan
Membangun Usaha yang Islami). Jakarta: Lini zikrul media intelektual Yin, Robert K. 1987. Studi Kasus: Desain dan Metode. Terjemahan oleh M. Djauzi Mudzakir, 2009. Jakarta: Rajawali Pers

Yusanto, M. I dan M. K. Widjajakusuma. 2002. Menggagas Bisnis Islami. Jakarta: Gema Insani Press

Zaroni, Akhmad Nur. 2007. Bisnis Dalam Perspektif Islam (Telaah Aspek Keagamaan dalam Kehidupan Ekonomi) Mahazib. Vol. IV. No.2 m.liputan6.com www.republika.co.id 